〔102〕高分子電解質の溶液挙動に及ぼす分岐の影響

(1962 年 4 月 5 日受理)

桜田一郎*・坂口康 義**.土屋 静雄*

\begin{abstract}
要 旨 同一重合度 (7000) を持つ直鎖および分岐 (1 分子あたりの分岐単位数は約 8) ポリビニルア ルコール分別物を, グリオキシル酸および oーフタルアルデヒド酸によって同一反応度まで部分アセタール化 した。カルボキシル基を含むこれら試料は㨁鎖および対応する分岐ポリマーに対してほとんど同一の電压滴定 挙動を示した。しかし, 希薄水溶液の粘度は直鎖ポリマーの方が 分岐ポリマーよりかなり高かった。また 0 フタルアルデヒド酸による部分アセタール化ポリビニルアルコールは少し異常な粘度挙動を示した。これらの 結果に対して若干の考察を行なった。
\end{abstract}

\section{1. 粕言}

非電解質高分子の希薄溶液の挙動に及ぼす分岐の影響 については従来若干の研究が行なわれている。著者らも この点に関してポリ酢酸ビニル $(\mathrm{PVAc})$ を用いて検郡を

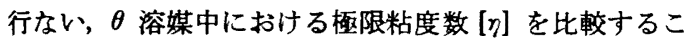
とによって 1 分子中の少数の長い分岐の数をほぼ定量的 に求めうることを明らかにしている゙”。高分子電解質の 希薄溶液の挙動に及ぼす分岐の影響についても，分岐密 度がかなり高い場合については若干の研究が行なわれて いるが2，わずかの分岐の影響について検討されている 報告は著者らの知るかぎりではない。それ㠴え著者らは 同一分子量を有する直鎖および少数の分岐を持つ分岐ポ リビニルアルコール (PVA) を製造し,これらにグリオ キシル酸および タール化によってカルボキシル基を導入し，得られた試 料の希薄水溶液の電圧滴定ならびに粘度挙動を比較検討 した。

\section{2. 試料の製造}

\section{1 原料ポリビニルアルコール}

本研究の目的には, 重合度の等しい直鎖および分岐ポ リマー試料を用いることが望ましい。それゆえ，次に示 す方法に従って直鎖および分岐 PVA を製造し，これら を分別して，それぞれから重合度のほぼ等しい区分を選 び出してアセタール化の原料供した。

\subsection{1 直鎖 PVA}

VAcに $-78^{\circ} \mathrm{C} て ゙ \gamma$ 線照射を行なって得られた塊状 重合物を, 分岐を除くために常法によりヶン化し, 得ら れた PVA を常法により再酢化，ついで分別沈殿法によ りアセトンー水系で 10 区分に分別した。分別物のアセト ン溶液の $[\eta]$ を求め, この值が次に述へる分岐 PVAc 分別物の $[\eta]$ とほぼ一致した区分 (第 3 区分) を再ケン 化してPVA に変えた。

\footnotetext{
* 京都大学工学部高分子化学教室(京都市左京区吉田本町)
}

** 甲南大学理学部応用化学教室 (神戸市東淮区本山町岡本)

\subsection{2 分岐 PVA}

$0.02 \%$ AIBN を開始剂に用いて $30^{\circ} \mathrm{C} て ゙$ 塊状重合を 行なって得られた PVAc をケン化して PVA に変え た。予備実験の結果に基きこのPVAの $10 \%$ 水溶液 に室温で $\gamma$ 線を $2 \times 10^{5} \mathrm{r} / \mathrm{hr}$ の線量率で 5 時間照射を 行なった。得られた分岐 PVA を酢化してPVAcに変 え, 分別した。分別物のアセトン溶液の $[\eta]$ を求め, 第 3 区分の $[\eta]$ が前述した直鎖 PVAc の第 3 区分のそれ とほぼ一致することを認めたので，この区分をケン化し て PVA に変えた。

Fig. 1 に示すように, アセタール化の原料に用いた直 鎖 (L) PVA と分岐 (B) PVA の PVAc としての [n]

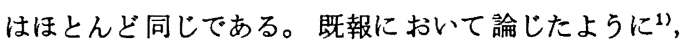
分岐があまり多くないかぎり，PVAc の重合度とアセ卜 ン溶液の $[\eta]$ との関係は分岐にほとんど無関係であると 考えることができるから，ここに用いた L- および B-

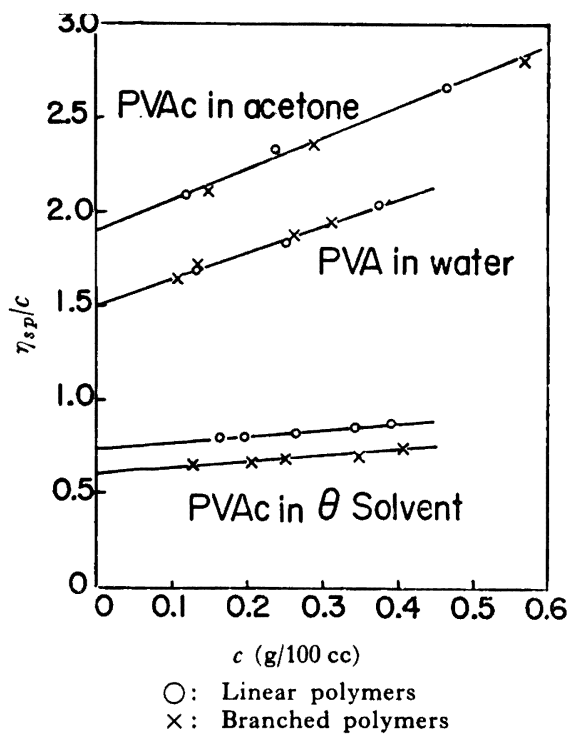

Fig. 1. Viscosity of PVA and PVAc. 
PVAc の重合度, したがってそれぞれに対応するL一お よび B-PVA の重合度はほとんど同一であると見なす ことができる。両 PVAc の重合度を $[\eta]$ から中島らの 式孚有いて算出すると約 7000 となる。

次に緒言において述べた既報の結果" ${ }^{11}$ 基いて BPVAc，したがって B-PVA の分岐数を求めた。すなわ ち L- および B-PVAc の $\theta$ 溶媒（容積比でアセトン: イソプロパノール $=23: 77,30^{\circ} \mathrm{C}$ ) 中の $[\eta]$ を測定した。 この結果は Fig. 1 に示すとおりであり, L-PVAc の方

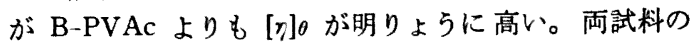
$[\eta] \theta$ から (1) 式を用いて $g$ 值を算出し, $g$ の值から Zimm-Stockmayer の理論式" を用いて B-PVAc, 1 分 子中の分岐点の数を算出すると, 3 官能分岐として約 8 , 4 官能分岐として約 4 の値が得られた。

$$
g=\left\{\begin{array}{l}
{[\eta]_{\theta, \mathrm{B}}} \\
{[\eta]{ }_{\theta, \mathrm{L}}}
\end{array}\right\}^{2}=\left(\frac{0.58}{0.72}\right)^{2}=0.65
$$

なお両 PVA 試料の水溶液の粘度も測定したが,この 結果は Fig. 1 に示すとおりで, 両試料の [ク] はほとん ど一致している。

\subsection{PVA のアセタール化}

2.1 で得られた L- および B-PVA にカルボキシル 基を導入する目的で，カルボキシル基を含むアルデヒド によって部分アセタール化を行なった。

2.2.1 グリオキシル酸によるアセタール化

PVAの $0.7 \%$ 水溶液に PVAの 0.40 あるいは 0.10 当量のグリオキシル酸および $2 \mathrm{~mol} / l$ の硫酸を加え, $60^{\circ} \mathrm{C}$ で 170 時間アセタール化を行なった。この条件で は反応中に PVA 分子の切断がほとんど起こらないこ とがすでに認められている゙う。反応後の溶液は $\mathrm{NaOH}$ を加えてアルカリ性とし，透析，ついでイオン交換樹脂 通過によって精製を行ない, 酸型水溶液とした。この溶 液についてポリマー濃度(秤量法)およびカルボキシル基 含有量(電圧滴定法)を測定し、これらの值から試料のア セタール化度を求めた。この結果は Table 1 に示すと おりであり，L- および B- ポリマーに対するアセター ル化度はほぼ一致している。

2.2 .2 o-フタルアルデヒト酸によるアセタール化 次にPVA をグリオキシル酸よりも弱酸である 0 -
タルアルデヒド酸によってアセタール化した。PVA $0.7 \%$, PVAの 0.30 当量のアルデヒド, 捛よび $2 \mathrm{~mol} / l$ $\mathrm{H}_{2} \mathrm{SO}_{4}$ を含む水溶液を $60^{\circ} \mathrm{C}$ に加熱すると，まもなく反 応液が白濁した。それゆえ，ここで反応液にボウ硝を加 えてポリマーを沈殿分離させ，ボウ硝水溶液ついで泠水 で洗浄後, $0.1 N-\mathrm{NaOH}$ 水溶液に溶解し, イオン交換樹 脂を通して精製した。2.2.1 に述べた方法に従って反応 生成物のアセタール化度を求めた。この結果は Table 1 に示すとおりであり，L- および B- ポリマーに対する アセタール化度はほほ一定している。

\section{3. 水谘液の奄圧滴定}

Table 1 に示した各試料の水溶液について，堀場製作 所製 $\mathrm{P}$ 型 $\mathrm{pH}$ メーターを用いて $0.1 \mathrm{~N}-\mathrm{NaOH}$ 水溶液 により電圧滴定を行なった。この結果は Fig. 2 に示す とおりであり，いずれのアセタール化物についても，滴 定曲線には分岐の影䭗はほとんど認められない。これら の試料は電離基密度があまり高くなく，また $\mathrm{B}$-ポリマ 一の分岐数が小さいために，このよらな結果をきたした ものと思われる。

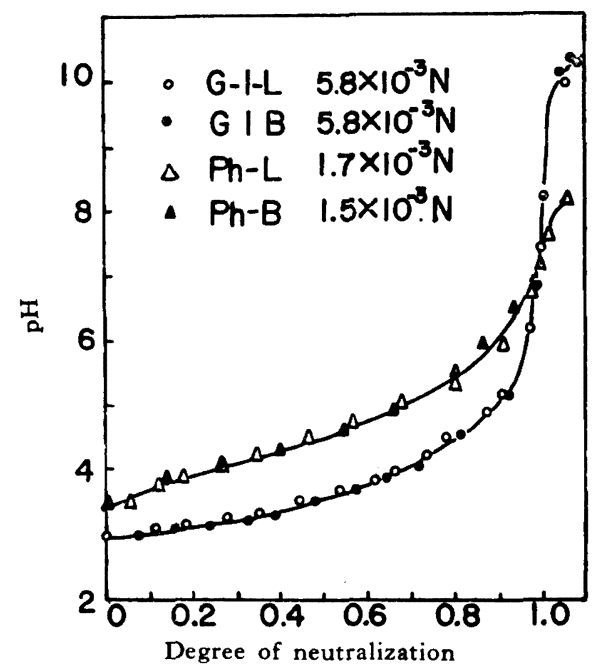

Fig. 2. Potentiometric titration curves of partially acetalized PVA with glyoxylic acid and $o$-phthalaldehydic acid $\left(0.1 \mathrm{~N}-\mathrm{NaOH}, 20^{\circ} \mathrm{C}\right)$.

Table 1. Partially acetalized PVA samples with glyoxylic acid or $o$-phthalaldehydic acid.

\begin{tabular}{|c|c|c|c|c|c|c|}
\hline Samples & G-1-L & $G-1-B$ & G-2-L & G-2-B & $P-L$ & $P-B$ \\
\hline Aldehyde for acetalization & \multicolumn{4}{|c|}{ Glyoxylic acid } & \multicolumn{2}{|c|}{$o$-phthalaldehydic acid } \\
\hline Branching & Absent & Present & Absent & Present & Absent & Present \\
\hline Degree of acetalization, $\mathrm{mol} \%$ & 35.6 & 32.8 & 5.2 & 5.6 & 15 & 13 \\
\hline
\end{tabular}




\section{4. 水溶液の粘度}

次に各試料の水溶菠の粘度を, ウべード型粘度計を 用いて測定した。グリオキシル酸によるフセタール化 PVA に関子る実験結果は Fig. 3 に示すとおりである。 $0.2 \mathrm{M}-\mathrm{NaCl}$ を添加して惺䧹基の影警を抑制した場合の 粘度は，各試料に対してほほ同一であるが、純水中に打 ける粘度は B-ポリマーの方が，Lーポリマーよりも明り ように低い。

のフタルアルデヒド踆によるフセタール化PVAに関 する実験結果は Fig. 4 に示した。両試料の純水中にお ける粘度は，ポリマー浱度が滈くなるとほぼ一致してい

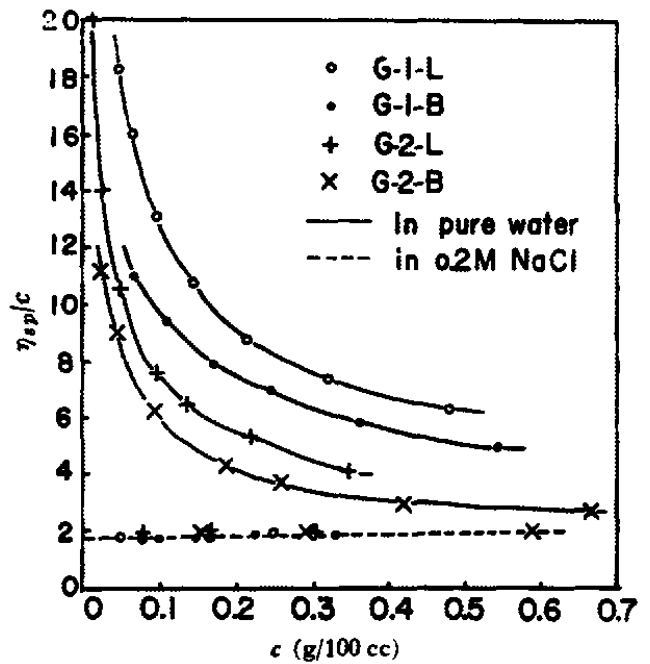

Fig. 3. Viscosity of partially acetalized PVA with glyoxylic acid in water $\left(30^{\circ} \mathrm{C}\right)$.

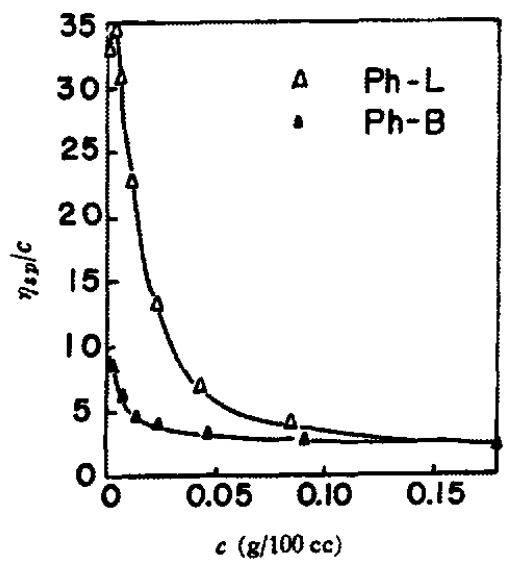

Fig. 4. Viscosity of partially acetalized PVA with 0 -phthalaldehydic acid in water $\left(30^{\circ} \mathrm{C}\right)$.
るが，低篮库では B-ポリマーの方が Lーポリマーより む明りょらに低い。なおこれらの試料においては，水溶 液に $0.2 M-\mathrm{NaCl}$ を添加すると ポりマーの沈欵をきた した。

高分子電解兵の水溶液において，ボリマー漕度が低下 すると，同一ポリマー分子中の電離基間の静電反発作用 が増大してポリマー分子はより延びた形をとりここのた

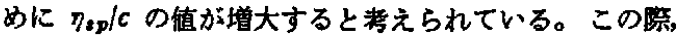
分岐ボリマーは值鎖ボリマーはとにはは延びた形をとりえ ないので，低䈨度溶液の $\eta_{s p} / c$ が後者より明りょ5に低 くなるむのと毒えられる。このよ5に高分子の分歧が溶

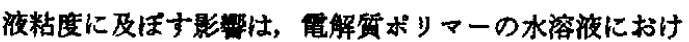
る方が，既述の非䉓解犋ポリマーの $\theta$ 溶液におけるよ りもさらに大きく，したがって高分子電解梊の希薄水溶 液の粘度を比較検討することは，ポリマー分子中の少数 の長い分䑩の存在を調へるための有力な一手段となりら ると考えられる。

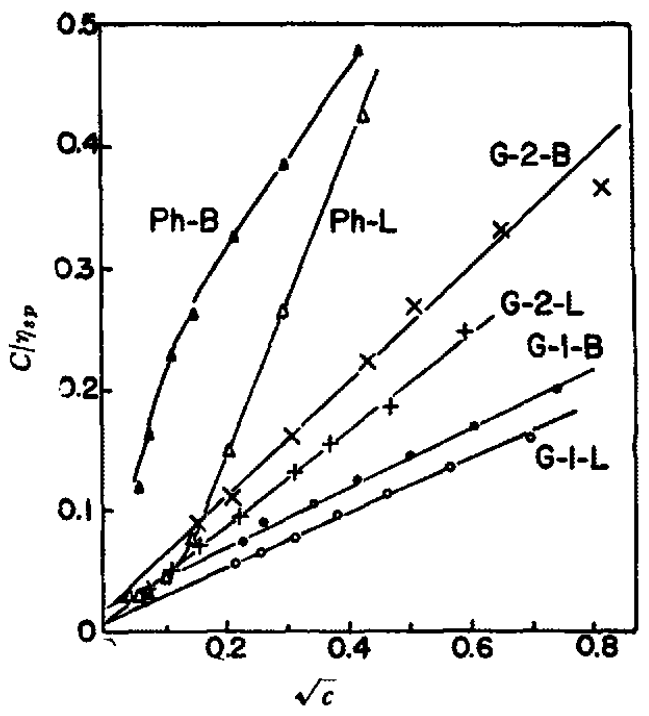

Fig. 5. Fuoss' plots for viscosity of partially acetalized PVA in water $\left(30^{\circ} \mathrm{C}\right)$.

次に (Ph) の粘度举動をグリオキシル酸によるアセタール化 物（G）のそれと比較すると，溶液灌度の低下に伴って $\eta_{s p} / c$ が増大寸るとい5高分子電解罂特有の举動が, 前 者ではごく低灙度にならないと明りょらに現われないと い5㑯向が認められる。各試料について Fuoss の式

(2) 式に従って $c / \eta_{\diamond p} \sim \sqrt{ } \bar{c}$ プロットを行なった結果 は Fig. 5 に示すとおりである。

$$
\frac{c}{\eta_{s p}}=A+B \sqrt{c}
$$


G についてはごく低浱度䈖囲を除いてほぼ直線関係 が得られる。直鎖状 $\mathrm{Ph}$ についても低濃度範囲を除いて ほぼ直線関係が得られるが，直線の傾斜は $\mathrm{G}$ の場合よ りも著しく大きく，低濃度における $\eta_{s p} / c$ は G-L とほ ぼ一致している。また分岐 $\mathrm{Ph}$ では前述のプロットは直 線関係から明りょらに外九ている。

このよらな事実は $\mathrm{Ph}$ 中のカルボキシル基が $\mathrm{G}$ 中の それよりやや電離しにくいといら事実のみによっては理 解できない。最近スチレンと無水マレイン酸の共重合物 の加水分解物の $\mathrm{HCl}$ 水溶液中の粘度が 異常に小さいこ とが指摘され，これは同一ポリマー分子中のスチレン基 本分子間の 相互作用に基くと考えられている ${ }^{6)}$ 。 $\mathrm{Ph} に$ おいてもベンぜン核の間にこれと同様な相互作用が存在 し、このために溶液漉度を低下させてもポリマーコイル
は広がりにくく,ずっと低濃度になり静電反発作用が前 述の相互作用に打ち勝つよらになって，はじめてポリマ ーコイルが顕著に広がるものと思われる。この点に関し ては現在さらに検討を行なっている。

\section{文献}

1）桜田一郎, 土屋静雄, 其; ; “義：高化, 18, 346 (1961)

2）井上友治：日化, 77, $\varepsilon, 1956)$

3）中島章夫, 古館勝正: 容化, 6, 460(1949)

4) B. H. Zimm et al : J. Chem. Phys., 17, 1301(1949)

5）桜田一郎, 坂口康義, 媣見健右, 高島勝治：高化, 投稿中

6) W. Dannhauser et al : J. Phys. Chem., 64, 954 (1960)

\title{
The Effects of Branching on the Solution Behaviors of Polyelectrolytes
}

\author{
By Ichiro Sakurada*, Yasuyoshi Sakaguchi** and Shizuo Tsuchiya*
}

\begin{abstract}
Linear and branched (numbers of branched units per molecule were about 8) polyvinyl alcohol fractions of the same degree of polymerization $(7,000)$ were partially acetalized with glyoxylic acid or $o$-phthalaldehydic acid. The potentiometric titration behaviors of linear polymers were almost the same as those of corresponding branched polymers with the same amount of $\mathrm{COOH}$ groups. On the other hand, the viscosity of dilute aqueous solutions of linear polymers were considerably higher than those for branched polymers. PVA samples partially acetalized with $o$-phthalaldehydic acid showed abnormal behaviors of the viscosity. Some discussions were given for these results.
\end{abstract}

* Department of Polymer Chemistry, Kyoto University (Kyoto)

** Department of Applied Chemistry, Konan University (Higashinada-ku, Kōbe)

昭和 37 年 10 月 20 日印刷昭和 37 年 10 月 25 日 発行 第 19 巻第 210 号・1962 高分子化 学

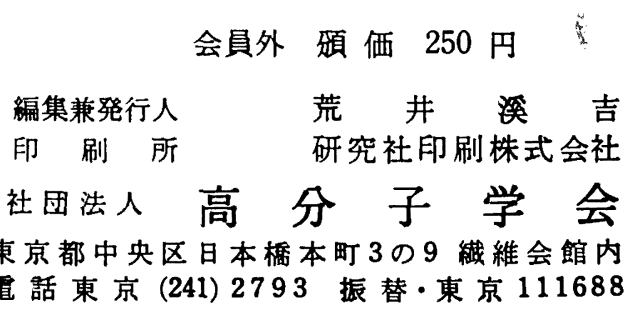

